\title{
Optimized protocol to isolate high quality genomic DNA from different tissues of a palm species
}

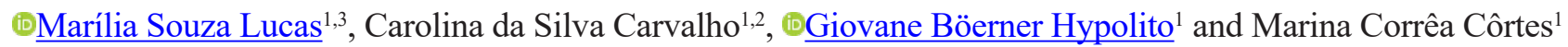 \\ Received: 18 October 2018; accepted: 29 April 2019 \\ How to cite: Lucas, M.S., Carvalho, C.S., Hypolito, G.B.H. \& Côrtes, M.C. 2019. Optimized protocol to isolate high quality \\ genomic DNA from different tissues of a palm species. Hoehnea 46: e942018. http://dx.doi.org/10.1590/2236-8906-94/2018.
}

\begin{abstract}
Optimized protocol to isolate high quality genomic DNA from different tissues of a palm species). The application of molecular techniques to tackle ecological and evolutionary questions requires genomic DNA in good quality and quantity. The quality of the isolated DNA, however, can be influenced by the tissue type and the way the sample was conserved and manipulated. Therefore, customizing protocols to improve the DNA isolation and locus amplification is crucial. We optimized a cheap and manual protocol of DNA extraction and microsatellites amplification using five different tissues of a palm species of the brazilian Atlantic Forest. We successfully extracted DNA from all five tissue types. Leaf, stem, and endocarp of non-dispersed seeds presented the highest rates of successful DNA extraction and microsatellite amplification; whereas root, endocarp of dispersed seeds, and embryo showed the lowest quality and quantity. Based on these results, we discussed the implications of using different tissues for studies about seed dispersal, pollination, and population genetics.

Keywords: DNA extraction, Euterpe edulis, microsatellite, tropical palm
\end{abstract}

RESUMO - (Protocolo otimizado para isolar DNA genômico de alta qualidade em diferentes tecidos de uma espécie de palmeira). A aplicação de técnicas moleculares para lidar com questões ecológicas e evolutivas requer DNA genômico de boa qualidade e quantidade. A qualidade do DNA isolado, no entanto, pode ser influenciada pelo tipo de tecido e pela maneira como a amostra foi conservada e manipulada. Portanto, personalizar protocolos para melhorar o isolamento do DNA e a amplificação dos locus é crucial. Nós otimizamos um protocolo barato e manual de extração de DNA e amplificação de microssatélites utilizando cinco diferentes tecidos de uma espécie de palmeira da Mata Atlântica brasileira. Nós extraímos com sucesso o DNA de todos os cinco tipos de tecidos. Folha, caule e endocarpo de sementes não dispersas apresentaram as maiores taxas de extração de DNA e amplificação de microssatélites; enquanto raiz, endocarpo de sementes dispersas e embrião apresentaram a menor qualidade e quantidade. Com base nesses resultados, discutimos as implicações do uso de diferentes tecidos para estudos sobre dispersão de sementes, polinização e genética de populações.

Palavras-chave: extração de DNA, Euterpe edulis, microssatélite, palmeira tropical

\section{Introduction}

Molecular tools have been used to answer different ecological and evolutionary questions, and the isolation of DNA in good quantity and quality is a critical step towards the development of these studies (Haig, 1998, Allen et al. 2006). DNA isolation may be particularly challenging for small, degraded samples or containing high concentrations of polysaccharides, phenolic substances, and secondary compounds (Rogers \& Bendich 1994). For example, DNA extraction from plants is inherently more difficult than from animals, first because plants have cell wall and lignin (Varner \& Lin 1989) that require maceration steps to be broken, and second because plants often contain secondary compounds that can inhibit PCR (Khanuja et al. 1999). Therefore, customizing protocols are important to improve DNA isolation and optimize the amplification of the desired DNA regions (Solléro et al. 2004).

In plants, DNA can be extracted from various tissues, such as leaf, stem, root, fruit endocarp and embryo. These tissues can be used to answer different ecological and microevolutionary questions. Leaf and stem, for example, are often used in population genetics

1. Universidade do Estado de São Paulo, Instituto de Biociências, Departamento de Ecologia, Av 24 A,1515, 13506-900 Rio Claro, SP, Brasil

2. Instituto Tecnológico Vale, R. Boaventura da Silva, 955 - Nazaré, 66055-090 Belém, PA, Brasil

3. Corresponding author: marilia_souza2@hotmail.com 
studies (Hamrick \& Loveless 1989, Ledig \& Conkle 1983, Gaiotto et al. 2003). These studies aim to explain the influence of processes such as natural selection, genetic drift, and gene flow on the distribution of allelic frequencies in natural populations (Ouborg \& Van Groenendael 1991, Hamrick 1992). The endocarp, a fruit tissue of maternal origin, can be used in studies of seed dispersal (Godoy \& Jordano 2001). Seed dispersal distance can be more accurately estimated using maternity analysis (García \& Grivit, 2011). This analysis consists of identifying the most likely mother plant of dispersed seeds based on genotype matching between adult plants and the maternal tissue of the progeny (i.e., endocarp) (Godoy \& Jordano 2001, García et al. 2009). The embryo, in turn, can be used in pollination and reproductive system studies. To characterize the progenies, most studies use seedling leaves recruited from seeds directly collected from the parent plants (Tarazi et al. 2013, Sobierajski 2006). However, using embryo tissue directly can cost less than that of seedlings leaf because it does not depend on germination and seedling development, saving time and resources. Furthermore, in contrast to sampling seedlings that depend on successful germination, the direct use of embryos allows evaluating the genotype of all sampled progenies. Because it is a biparentally inherited tissue, the embryo can be used to characterize demographic parameters related to plant reproduction including the effective size of the reproductive neighborhood, the relatedness of progenies, and pollen dispersal (Ellstrand 1992, Gonzalez-Varo et al. 2009).

The use of molecular techniques to answer these ecological and evolutionary questions requires the obtention of genomic DNA in good quantity and quality (Waldschimidt 1999), which can be influenced by the tissue type and also by how the sample is manipulated by the researcher (Varma et al. 2007). For example, younger tissues, especially the leaves, produce DNA of good quality and quantity due to large numbers of cells and small amounts of secondary metabolites (Murray et al. 1980, Williams et al. 1994). But stem or root tissues are preferred when tree crowns are too tall to reach for leaves (Lanes et al. 2013). Nevertheless, these tissues are more lignified and may present secondary compounds, which can hinder the isolation of the genetic material (Lewinsohn et al. 1994) or inhibit the polymerase chain reaction (PCR) used to amplify the loci of interest (Schori et al. 2013). For example, some species with exposed roots have high amounts of secondary compounds that act as natural defense pesticides, mainly against herbivores and infections by pathogenic microorganisms (Bourgaud 2001). Another tissue type, the endocarp of dispersed seeds, can be degraded due to chemical and physical abrasion during the passage through the digestive tract of frugivorous animals (Marrero et al. 2009) and, due to the effects of humidity, pathogens (e.g., fungi) and parasites (e.g., borer beetles) after seeds are exposed in the soil. The seed may also come into contact with new substances in the environment, for example, the presence of humic acids in the soil (Puglisi 2013), which can decrease the quality of the isolated DNA and inhibit PCR.

Because of the variation in quality and quantity of isolated DNA from plant tissues, it is important that DNA extraction and amplification protocols are optimized to ensure desirable results. The objective of this study was to optimize an inexpensive and manual protocol of DNA extraction from five different tissues of the Atlantic Forest palm species Euterpe edulis Mart. For this, we tested different concentrations and/or addition of reagents such as cetyl trimethylammonium bromide (CTAB), sodium chloride $(\mathrm{NaCl})$, polyvinylpyrrolidone (PVP), proteinase $\mathrm{K}, \beta$-mercaptoethanol, sarkosyl and sorbitol to improve of DNA extraction of degraded, contaminated samples or containing high concentrations of secondary metabolites (Varma et al. 2007). We also report a DNA amplification protocol using microsatellite loci, in which we obtained high quality results even using low amounts of DNA template. Although developed for one palm tree species, the described protocols of DNA isolation methods may extend, or, at least be theoretically useful, for carrying out genetic studies in plant species with similar ecological characteristics.

\section{Material and methods}

\section{Species of study}

We used as model species the palm Euterpe edulis, commonly known as Juçara palm (figura 1). The Juçara palm holds great ecological (Galetti et al. 1999, Reis \& Kageyama 2000) and economic (Brancalion et al. 2012, ITESP 1998, Souza 2014) importance. It is a widely studied species, with studies spanning from organismal biology, palm heart production to genetics and conservation (Dos Reis et al. 2000, Carvalho et al. 2015, Galetti et al. 2013).

Pollination and seed dispersal processes of the Juçara palm are carried out by animals (Gaiotto et al. 


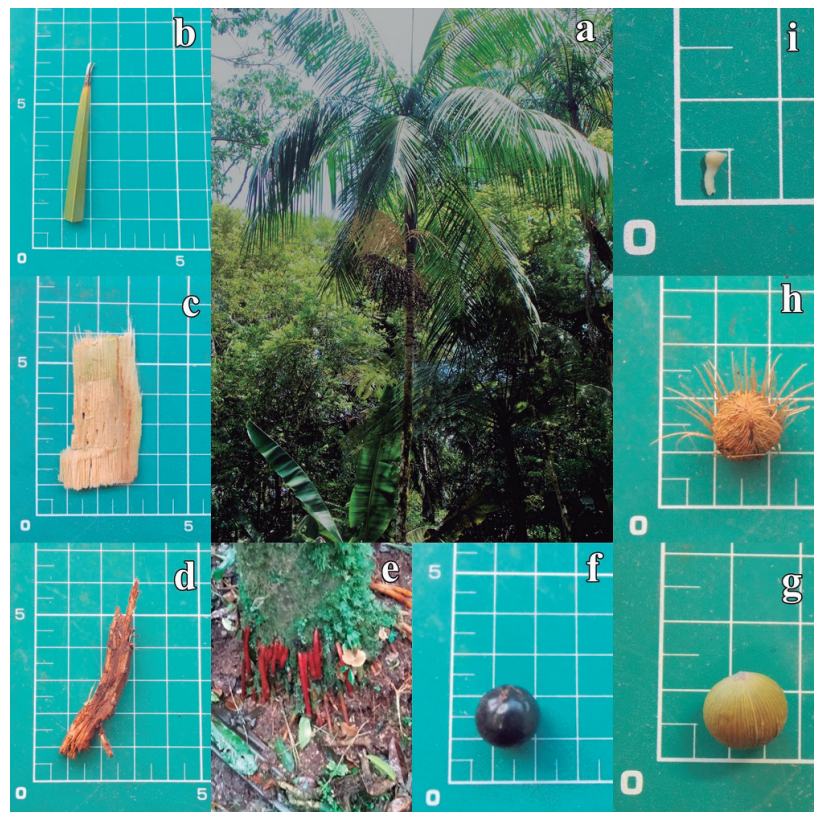

Figure 1. Tissue types from the palm tree Euterpe edulis. a. Adult tree. b. Leaf. c. Stem stalk. d. Root. e. Root detail. f. Ripe fruit. g. Fruit without pulp (endocarp of not dispersed seeds). h. Endocarp of dispersed seeds. i. Seed embryo.

2003, Galetti et al. 2013). Pollination can be done by a myriad of insects (entomophily), including: bees, wasps (both Hymenoptera), flies (Diptera), beetles (Coleoptera) and butterflies (Lepidoptera) (Mantovani \&Morellato 2000). Less importantly, wind can also contribute to pollination (anemophily) (Seoane et al. 2005). Due to the production of large crop size, long and annual fruiting, and wide variation in fruit size, the Juçara palm is an important food source for more than 50 species of birds, such as large (toucans, cotingas and guans) and medium-size birds (thrushes) and some mammals (Galetti et al. 2013).

This palm is composed of a single stem with leaves at the apex. Leaves, disposed in an alternated fashion, are composed and pinned, with a sheath that protects the apical meristem (palm heart). The inflorescence of spike type is composed by approximately 150 male and 50 female flowers (Gaiotto et al. 2003, Seoane et al. 2005). The seed, about $12 \mathrm{~mm}$ wide, is globose shaped and fills most of the fruit (Accorsi \& Barros 1974). The endocarp, which provides the tissue used for maternity analysis in Euterpe edulis, consists of membranous fibers attached to the seed (Accorsi \& Barros 1974).

\section{Sampling of plant tissues}

We sampled 10 adult palms by collecting fragments of stem, leaf, root, and seeds (for embryo and endocarp extraction) (figure 1). We also randomly collected 10 dispersed seeds directly from the ground in an Atlantic forest patch located in the Serra do Mar São Paulo State Park - Santa Virgínia, Brazil. Differently from the seeds collected directly from the trees, these dispersed seeds passed through the digestive tract of the animals and had been exposed to soil environmental conditions such as high humidity, presence of fungi and pathogens and humic acids.

Plant samples were placed in individualized paper bags and then enclosed in a plastic bag with silica gel for drying. After dehydration, the tissues were frozen at $-20^{\circ} \mathrm{C}$ for better preservation. The fruits removed directly from the palms were pulped for the extraction of the seed and the attached endocarp. After sampling the endocarp, seeds were crack opened to remove the embryo embedded in the endosperm (figure 1).

\section{DNA Extraction}

We isolated DNA from the different tissues using a Cetyl trimethylammonium bromide (CTAB) protocol adapted from BG Milligan (1989) for isolation of plant DNA (Doyle \& Doyle 1987). The general protocol (see description below) was used to extract DNA from leaves, stems, roots, embryos and endocarps of non-dispersed seeds. Additionally, we customized a protocol that provided better DNA quality for endocarps of dispersed seeds (procedure called as endocarp protocol).

In general, the extraction of total genomic DNA comprises of three distinct steps. The endocarp protocol differs only in the first step (I. Cell rupture).

\subsection{Materials and chemicals}

Microcentrifuge tubes (1.5 -2 mL)

7-mm-diameter beads

Pipettes and filter tips for volumes of $1000 \mu \mathrm{L}, 10 \mu \mathrm{L}$ and $200 \mu \mathrm{L}$

Beadbeater machine (Biospec Products Inc.)

Beadbeater for 1.5-2 mL tubes (Biospec Products Inc.)

Heating block $\left(65^{\circ} \mathrm{C}\right)$ for $1.5-2 \mathrm{~mL}$ tubes

Vortex

Centrifuge with refrigeration

\section{Microwave oven}

Gel tray system, combs and a submerged horizontal electrophoresis cell

Gel documentation system with UV (MiniBis Pro Bio-Imaging Systems) 
CTAB extraction buffer 1\%: $1 \%$ CTAB, Tris- $\mathrm{HCl} 0.15$ $\mathrm{M}$ (pH8), $\mathrm{NaCl} 2.6 \mathrm{M}$, EDTA $2 \mathrm{mM}$ (pH 8)

CTAB extraction buffer 3\%: $3 \%$ CTAB, Tris- $\mathrm{HCl} 0.15$ $\mathrm{M}(\mathrm{pH}$ 8), $\mathrm{NaCl} 2.6 \mathrm{M}$, EDTA $2 \mathrm{mM}(\mathrm{pH} 8)$

Sodium Chloride $(\mathrm{NaCl}) 5 \mathrm{M}$ or Sodium acetate $5 \mathrm{M}$ Sorbitol extraction buffer - Tris- $\mathrm{HCl} 100 \mathrm{mM}$ (pH 9.5), EDTA $5 \mathrm{mM}$ (pH 8), sorbitol $0.35 \mathrm{M}, 1 \%$ PVP (added to the buffer just before use) and $\beta$-mercaptoethanol Sarkosyl: $3 \mathrm{M}$

CIA (24 Chloroform: 1 Isoamyl alcohol)

Proteinase K (Invitek Inc.)

Pure cold $\left(-20^{\circ} \mathrm{C}\right)$ isopropanol

$70 \%$ ethanol

Absolute ethanol (99.5\%)

Agarose

Gel Red (Biotium Inc.)

Low Mass Ladder (Invitrogen Inc.)

TBE 5\%: Trizma base $5 \mathrm{M}$, Boric Acid $3 \mathrm{M}$, EDTA $2 \mathrm{mM}(\mathrm{pH} 8)$

\subsection{Extraction Protocol}

I. Cell rupture: the tissue maceration is the first step in the DNA extraction from plant cells. The reagents contained in the extraction buffer are responsible for breaking the membranes and releasing the cellular content (DNA, proteins, etc). The proteinase $\mathrm{K}$ enzyme is added to denature the proteins, keeping the DNA intact.

\section{General Protocol - Step 1}

Place approximately $100 \mathrm{mg}$ of plant tissue (i.e., leaf without the veins, root, endocarp, stem or embryo) in $2 \mathrm{~mL}$ tubes. Add $7 \mathrm{~mm}$ beads for maceration. Macerate for 1 minute and 30 seconds in the macerator Mini-Beadbeater ${ }^{\mathrm{TM}}$ (depending on the lignification of the sample another maceration cycle is needed). Add $800 \mu \mathrm{L}$ of $1 \%$ CTAB buffer solution preheated at $65^{\circ} \mathrm{C}$ to each tube. Incubate the tubes at $65^{\circ} \mathrm{C}$ for 1-2 hours, preferably with gentle shaking.

\section{Endocarp Protocol - Step 1}

Place approximately $100 \mathrm{mg}$ of dispersed seed endocarp tissue in $2 \mathrm{~mL}$ tubes. Add $7 \mathrm{~mm}$ beads for maceration. Macerate the tissue for 1 minute and 30 seconds in the macerator Mini-Beadbeater ${ }^{\mathrm{TM}}$. Add $1 \mathrm{~mL}$ of cold Sorbitol extraction buffer $\left(4{ }^{\circ} \mathrm{C}\right)$ and $2 \mu \mathrm{L}$ of $\beta$-Mercaptoethanol to each tube and mix in a vortex for five seconds to neutralize the action of contaminants, such as polysaccharides polyphenols and other secondary metabolites (TelZur et al. 1999). After resting for 20 minutes in a 4 ${ }^{\circ} \mathrm{C}$ refrigerator, centrifuge the tubes for 10 minutes at $10000 \mathrm{rpm}$ at $4{ }^{\circ} \mathrm{C}$. Dispose of the supernatant. If necessary, the adding of Sorbitol extraction buffer and $\beta$-Mercaptoethanol should be repeated until the supernatant is clear. Add a mix of $800 \mu \mathrm{L}$ of $3 \% \mathrm{CTAB}$ extraction buffer preheated at $65^{\circ} \mathrm{C}, 30 \mu \mathrm{L}$ of sarkosyl and $2.5 \mu \mathrm{L}$ of proteinase $\mathrm{K}$ to each tube. Incubate the tubes at $65^{\circ} \mathrm{C}$ for $1-2$ hours with gentle shaking.

General and Endocarp Protocol - Step 2

After the incubation period, centrifuge the tubes at $13000 \mathrm{rpm}$ for 15 minutes, under a temperature of $22{ }^{\circ} \mathrm{C}$. Add $600 \mu \mathrm{L}$ of CIA (Chloroform and isoamyl alcohol, 24: 1) to each tube. Manually homogenize the samples and centrifuge at $13000 \mathrm{rpm}$ for 10 minutes at $6{ }^{\circ} \mathrm{C}$. Transfer the supernatant to a new $1.5 \mathrm{~mL}$ tube and add $600 \mu \mathrm{L}$ of CIA. Manually homogenize the samples and centrifuge at $13000 \mathrm{rpm}$ for 10 minutes at $6{ }^{\circ} \mathrm{C}$. Transfer the supernatant once again to a new $1.5 \mathrm{~mL}$ tube.

II. DNA precipitation and purification: isopropanol is used in this protocol to precipitate the DNA from the solution. The DNA pellet is washed to purify it to the maximum.

Add a mix of $5 \mathrm{M} \mathrm{NaCl}$ (or sodium acetate) and isopropanol to each tube at a volume equivalent to $10 \%$ and $70 \%$ of the recovered supernatant, respectively. Manually homogenize the samples and place the tubes in the freezer at $-14{ }^{\circ} \mathrm{C}$ for, at least, 2 hours (preferably overnight) for the precipitation of DNA. Centrifuge the tubes for $20-30$ minutes at $14000 \mathrm{rpm}$ at $16^{\circ} \mathrm{C}$. At this point the DNA pellet should be attached to the tube wall in the bottom, carefully dispose of the liquid. To improve the washing of the pellet, add $1000 \mu \mathrm{L}$ of $70 \%$ ethanol and manually and gently agitate until the pellet peels off the wall. Rest the tubes for 10 minutes and then centrifuge at $14000 \mathrm{rpm}$ at room temperature for 10 minutes. Repeat again the $70 \%$ ethanol wash after careful disposal of the liquid. The third and final washing step should be done using $1000 \mu \mathrm{L}$ of absolute ethanol.

III. DNA elution: at this stage the DNA pellet is dried and re-suspended in aqueous solution.

Dispose of all liquid and leave the tubes open at room temperature for air drying the DNA. Once the pellet is completely dry and free from ethanol, solubilize the DNA with $50 \mu \mathrm{L}$ of purified water or TE 
buffer (EDTA pH 8.0-0.5M e Tris-Cl pH 8.0-1M) and $1 \mu \mathrm{L}$ of RNase $10 \mathrm{mg} / \mathrm{mL}$. In order for the RNase to degrade the RNA molecules still present in the sample, incubate the tubes at $37^{\circ} \mathrm{C}$ for 1 hour. Tubes can stand overnight in a fridge (at $4{ }^{\circ} \mathrm{C}$ ) before DNA extraction evaluation and finally store in a freezer $\left(-20^{\circ} \mathrm{C}\right)$ for preservation.

\subsection{Evaluation of DNA extraction}

The DNA quantification was performed by applying a mix of $1 \mu \mathrm{L}$ of DNA and $1 \mu \mathrm{L}$ of running buffer (xylene cyanol, bromophenol blue, sucrose and the fluorescent GelRed) per sample in each well of $1.5 \%$ agarose gel, using $0.5 \% \mathrm{TBE}$ buffer. One (1) $\mu \mathrm{L}$ of Low Mass ladder (Invitrogen Inc.) with $1 \mu \mathrm{L}$ GelRed dye was also added in one well of each race line to assign amount of DNA from each sample. The electrophoresis was set at $110 \mathrm{~V} / \mathrm{cm}$ for 40 minutes. The electrophoresis gel was visualized under UV light and registered using the gel documentation system MiniBis Pro (Bio-Imaging Systems). The DNA extraction success was evaluated by quantifying the DNA of each sample in the agarose gel according to the bands determined by the Low Mass Ladder, which are $100 \mathrm{ng} / \mu \mathrm{L}, 60 \mathrm{ng} / \mu \mathrm{L}, 40 \mathrm{ng} / \mu \mathrm{L}, 20 \mathrm{ng} / \mu \mathrm{L}, 10 \mathrm{ng} / \mu \mathrm{L}$ and $5 \mathrm{ng} / \mu \mathrm{L}$ respectively (figure 2 ). The isolation of DNA was considered successful when a clear band of at least $10 \mathrm{ng} / \mu \mathrm{L}$ was visualized. The success rate for each plant tissue type was expressed by the proportion of successful DNA extractions considering the ten samples and the average DNA quantity was expressed as the mean quantity of DNA across the successful samples.

\section{PCR (Polymerase Chain Reaction)}

4.1 Material and chemicals

PCR thermal cycler.

PCR-strips or 96-well plates.

Gel tray system, combs and a submerged horizontal electrophoresis cell

Gel documentation system with UV light

PCR pipettes and tips $(1000 \mu \mathrm{L}, 200 \mu \mathrm{L}$, and $10 \mu \mathrm{L}$ filter tips).

Enzyme: Taq DNA polymerase (GeneDireX Inc.)

Buffer: Taq DNA polymerase buffer (Biolase Inc.)

Bovine Serum Albumin (BSA) - stocked at $62.5 \mathrm{mg} /$ $\mathrm{mL}$

dNTPs (stocked at $10 \mathrm{mM}$ of each of dATP, dCTP, $\mathrm{dGTP}$, and dTTP in a mixture)

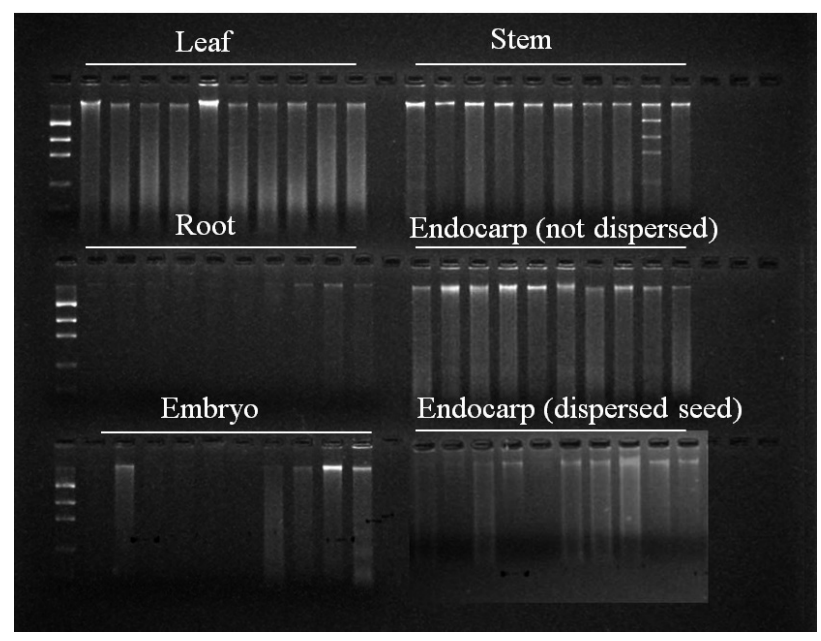

Figure 2. Electrophoresis gel with the results of Euterpe edulis genomic DNA extraction from five plant tissue types using two DNA extraction protocols: leaf, stem, root, non-dispersed seed endocarp and embryo using the general protocol, and dispersed seed endocarp using the endocarp protocol (see text). The Low Mass ladder (Invitrogen) was used for DNA quantification; the bands refer to $100 \mathrm{ng} / \mu \mathrm{L}, 60 \mathrm{ng} / \mu \mathrm{L}, 40 \mathrm{ng} / \mu \mathrm{L}, 20 \mathrm{ng} / \mu \mathrm{L}, 10 \mathrm{ng} / \mu \mathrm{L}$ and $5 \mathrm{ng} / \mu \mathrm{L}$, from top to bottom, respectively.

The forward and reverse microsatellite primers both extended at the $5^{\prime}$ - stocked at $0.9 \mathrm{mM}$ (EE3, EE23, EE25, EE45, EE47, EE52 and EE54)

Magnesium Chlorine $\left(\mathrm{MgCl}_{2}\right)$ - stocked at $50 \mathrm{mM}$.

Milli-Q Water

Agarose

DNA Ladder (50 bp Invitrogen Inc.)

Gel Red ${ }^{\mathrm{TM}}$ (Biotium Inc.)

\subsection{DNA amplification}

The PCR technique was used to amplify seven microsatellite loci (table 1). We optimized PCR protocols for dispersed seed endocarp (Endocarp) and the other tissues (General) (table 2) based on Gaiotto et al. (2001).

DNA amplification (for all tissues types) was performed using a touchdown program in the thermal cycler as follows: Initial denaturation at $95{ }^{\circ} \mathrm{C}$ during 3 minutes followed by 10 cycles comprising denaturation at $94{ }^{\circ} \mathrm{C}$ during 30 seconds, annealing of primers starting at the highest temperature (table 2) for 30 seconds followed by $1{ }^{\circ} \mathrm{C}$ decrease for every subsequent round until the lowest primer temperature is reached, and extension at $72{ }^{\circ} \mathrm{C}$ during 30 seconds. After these 10 cycles other 30 succeed, comprised of denaturation at $94{ }^{\circ} \mathrm{C}$ for 30 seconds, primer annealing at the lowest $\mathrm{T}{ }^{\circ} \mathrm{C}$ and extension at $72{ }^{\circ} \mathrm{C}$ for 30 seconds. And finally, a final extension at $72{ }^{\circ} \mathrm{C}$ for 7 minutes and cooling at $4{ }^{\circ} \mathrm{C}$ indefinitely. 
Table 1. Microsatellite molecular markers, respective primers sequences and expected variation of loci size in number of base pairs of the palm Euterpe edulis. Markers were originally described in Gaiotto et al. (2001).

\begin{tabular}{ccc}
\hline Primer & Sequence of primers (5'3') & Variation of allele size (bp) \\
\hline \multirow{2}{*}{ EE3 } & F: TTCgCgCACACTgAgAg & $194-210$ \\
& R: ggTAgCgTTgATTggTCC & \\
& FE : gTTCTgCgATTCATACTCCTg & $100-132$ \\
R: TACgAACCAAgATggAgCAA & \\
& F:CggATCCTgAgACTgAATTg & $156-190$ \\
EE25 & R:CACACAgATTCAgAgCACA & \\
& F: AAAgAAATTggCgTgACATC & $70-154$ \\
EE45 & R: AACCAgTCTTCTCCCTCTCg & $214-246$ \\
& F:CgAAATCAATggTTTCAgTg & \\
& R:AATTATTgTTgTgggCAgC & $230-260$ \\
\end{tabular}

\subsection{Evaluation of microsatellite loci amplification}

A mix of $2 \mu \mathrm{L}$ of the PCR product and $2 \mu \mathrm{L}$ of running buffer (xylene cyanol, bromophenol blue, sucrose and the fluorescent GelRed) was loaded into wells of $1.5 \%$ agarose gel and sized with the aid of the DNA ladder with the fluorescent GelRed. Electrophoresis was set at $110 \mathrm{~V} / \mathrm{cm}$ for 40 minutes. Gels were visualized using the gel documentation system.

PCR amplification was considered successful when a band appeared on the agarose gel at the expected size. Band occurrence correlates strongly with the success of genotyping, as demonstrated in other studies performed by our research group (Carvalho et al. 2018, Hypolito 2018, Lucas 2016). Even faint bands were considered as successful amplification because fragment size analysis in first generation sequencers (Sanger or capillary electrophoresis) is sensitive to low amounts of PCR products. The amplification success was reported as the proportion of successful amplification across the ten individuals for each of the seven loci for each tissue type.

\section{Results and Discussion}

Plant DNA may be difficult to isolate, but in general we extracted sufficient amounts of DNA and successfully amplified microsatellite loci of the tropical palm Euterpe edulis. DNA extraction and microsatellite amplification, however, varied considerably among tissue types (figure 2, table 3).
Leaf, stem and endocarp of non-dispersed seeds presented higher consistency and better results for both DNA extraction and PCR. DNA isolation from roots and embryos was less successful and microsatellite amplification was lower for DNA extracted from roots and endocarps of dispersed seeds (figure 2).

Plants generally have many secondary compounds that interfere with the DNA isolation process. Chemical reagents can be used to protect the DNA from oxidation and degradation from these substances during DNA isolation. Antioxidants, such as $\beta$-mercaptoethanol, BSA and PVP (Dawson \& Magee 1995, Clark 1997), are commonly used to deal with problems related to phenolic compounds (Puchooa 2004) and plant protection substances. For stem, leaf, embryo and endocarp of non-dispersed seeds, the addition of PVP was sufficient to ensure satisfactory quantity and quality of genomic DNA. For endocarp of dispersed seeds, however, the reagents $\beta$-mercaptoethanol, proteinase $\mathrm{K}$, sarcosyl and sorbitol had to be added to improve DNA extraction and microsatellite amplification. Regarding the PCR, as proposed by the protocol of Gaiotto et al. (2001), the use of BSA was indispensable for the amplification of the microsatellite regions, especially for tissues with lower DNA quantity, such as the endocarp and the embryo. The use of the touchdown program in the PCR thermal cycler, a method used to increase the specificity of PCR reactions (Korbie \& Mattick 2008), resulted in better results regardless of locus or tissue type.

Root samples, among all tissue types, presented the worst results regarding DNA isolation and, 


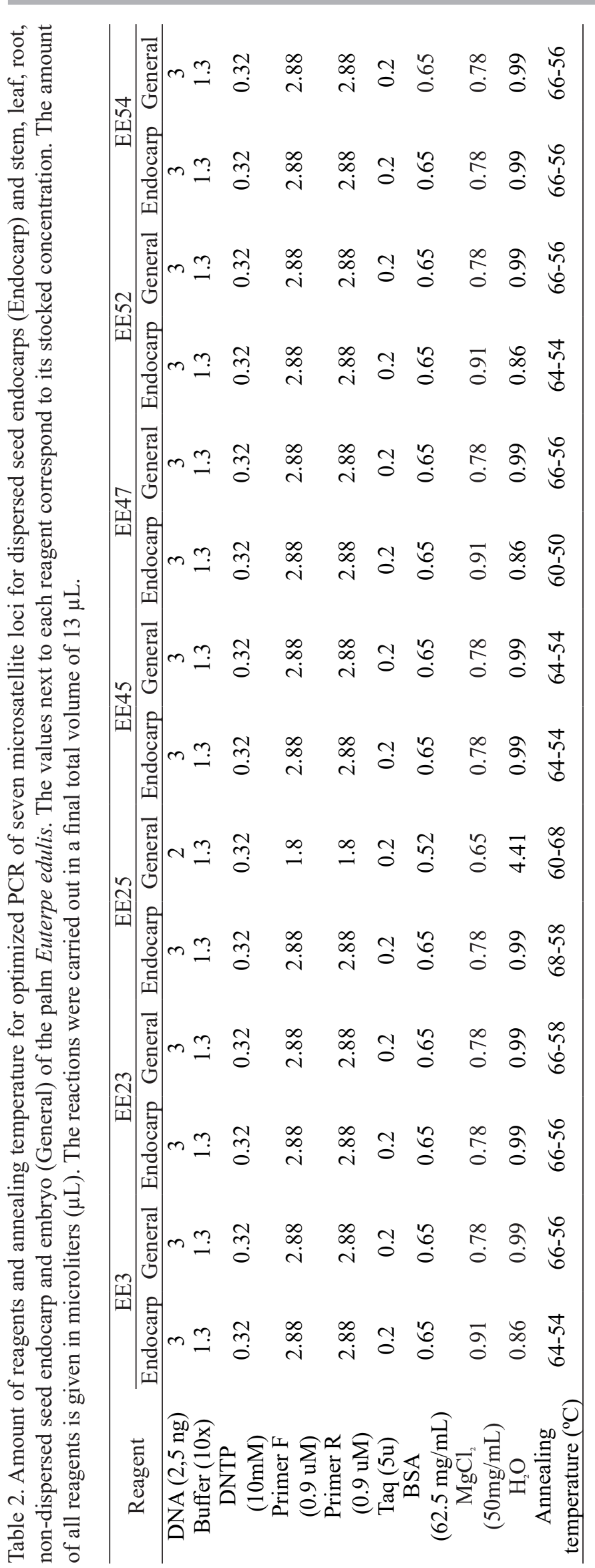

consequently, amplification of microsatellite loci. This may be due to the fact that $E$. edulis reddish roots are more susceptible to fungal contamination than other plant parts (Di Bonito et al. 1995) and can be exposed to humic acids from soil (Puglisi et al. 2013). On the other hand, the leaves and stems were the tissues providing the best results for DNA extraction and loci amplification. However, when comparing stem and leaf, leaves can be more difficult to obtain in the field because tree crowns can reach up to $20 \mathrm{~m}$, while stems are always accessible. Therefore, considering that leaf, stem and root have the same genetic material and that stem can be easily collected in the field, we recommend that stem should be sought in detriment of leaf and root tissues for genetic and genomic studies.

DNA extraction and microsatellite amplification from endocarps of dispersed seeds were also challenging. However, this tissue type provides results that no other can offer: being of maternal origin, the endocarp can be used in studies of seed dispersal and maternity (e.g. Godoy \& Jordano, Carvalho et al. 2019). The difficulties associated with DNA isolation and loci amplification are due mainly to the conditions that the seeds are submitted. These include the effects of the seed passage through the digestive tract of animals, direct contact with soil microorganisms and substances after dispersal and, finally, climatic variables such as precipitation and temperature that can exacerbate DNA degradation. Thus, to improve DNA isolation from endocarps of dispersed seeds, we added detergent, sarcosyl, and $\beta$-mercaptoethanol to the extraction buffer. These reagents solubilize membranes and assist in the inactivation and denaturation of some enzymes such as peroxidases and polyphenolodidases (Clemente 2010). After the addition of these reagents, the success of DNA extraction from dispersed endocarps increased but, the same success was not observed for microsatellite amplification. Other studies also show that the amplification success is generally low for dispersed seeds (Grivet et al. 2005, García et al. 2007). An important step towards better results is to go more regularly to the field, so that the seeds stay shorter periods on the ground where they are susceptible to the adverse conditions of the forest.

Contrary to the dispersed seeds, DNA extraction and microsatellite amplification of endocarps from nondispersed seeds were not challenging. In fact, this tissue allowed the extraction of large amounts of DNA and high amplification success. This can be explained by the fact that the seeds still attached to the mother trees do not 
Table 3. Rate of DNA extraction success (proportion of samples that presented bands in the agarose gel), average DNA amount ( \pm standard deviation), and rate of microsatellite amplification success (average, minimum and maximum number of loci that were successfully amplified) from 10 samples for each of the five tissue types of the palm Euterpe edulis.

\begin{tabular}{lcccccccccc}
\hline & $\begin{array}{c}\text { DNA } \\
\text { Tissue type } \\
\text { extraction } \\
\text { success \% }\end{array}$ & $\begin{array}{c}\text { Amount of } \\
\text { DNA }(\mathrm{ng} / \mu \mathrm{L})\end{array}$ & & \multicolumn{3}{c}{ Amplification success (\%) } & & $\begin{array}{c}\text { Amplification } \\
\text { success\% } \\
\text { [minimum, } \\
\text { maximum] }\end{array}$ \\
\hline & & & & & & & & & & \\
\hline Leaf & 100 & $140 \pm 53.2$ & 100 & 100 & 100 & 100 & 100 & 100 & 100 & $100[100,100]$ \\
Stem & 100 & $94 \pm 19.6$ & 90 & 90 & 100 & 100 & 100 & 100 & 80 & $95[80,100]$ \\
Root & 40 & $6 \pm 6.2$ & 50 & 0 & 50 & 40 & 20 & 80 & 10 & $40[20,80]$ \\
$\begin{array}{l}\text { Endocarp (not } \\
\text { dispersed) }\end{array}$ & 100 & $108 \pm 63.7$ & 100 & 100 & 100 & 100 & 100 & 100 & 100 & $98.75[90,100]$ \\
$\begin{array}{l}\text { Endocarp } \\
\text { (dispersed } \\
\text { seed) }\end{array}$ & 80 & $53 \pm 28.2$ & 50 & 60 & 50 & 70 & 70 & 40 & 50 & $56.25[40,70]$ \\
Embryo & 50 & $82.5 \pm 63.1$ & 70 & 70 & 80 & 90 & 70 & 80 & 80 & $75[60,90]$ \\
\hline
\end{tabular}

undergo the same adverse conditions as the dispersed ones. However, sampling directly from the mother tree does not provide any information about the processes of seed dispersal. The embryo, on the other hand, provides valuable information about the reproductive system and pollination. But, because the embryo is very small (about 2 to $5 \mathrm{~mm}$ ), the handling, maceration and pellet washing processes should be done carefully to prevent losing material and maximize sample homogenization. Once the DNA is successfully extracted, the amplification success is at its maximum. All individuals with adequate amounts of isolated DNA were successfully amplified, indicating that the extracted DNA also had a desirable quality.

In conclusion, we optimized two low-cost DNA extraction protocols (approximately 1/8 of the cost per sample when using the Qiagen plant tissue DNA extraction kit in Brazil) for five different tissue types and customized PCR protocols for amplification of seven microsatellites of a Brazilian Atlantic Forest palm tree. Even though the protocols were developed for one palm tree species, the described protocols can be tested and maybe applied to other plant species with similar ecological characteristics. Therefore, this study represents an important contribution for those who aim at investigating pollination, seed dispersal and genetic diversity and structure of plant species.

\section{Acknowledgments}

We thank CNPq for the financial support (CNPq 445353/2014-7). CSC e GBH were funded by FAPESP (2014/01029-5 e 2016/18235-2, respectively).

\section{Literature cited}

Accorsi, Walter Radamés, De Barros, Myrthes A.A. 1974. Morfologia do fruto e da semente de Euterpe edulis, Mart. Anais da Escola Superior de Agricultura Luiz de Queiroz, v. 31, pp. 701-711.

Allen, G., Flores-vergara, M., Krasnyanksi, S., Kumar, S. And Thompson, W. 2006. A modified protocol for rapid DNA isolation from plant tissues using cetyltrimethylammonium bromide. Nature Protocols 1: 2320-2325.

Barbosa Rodrigues, J. 1903 - Sertum Palmaram Brasiliensium. Imprimerie Tipographique Veuve Monnom. Bruxelles.

Bourgaud, F., Gravot, A., Milesi, S., Gontier, E. 2001. Production of plant secondary metabolites: a historical perspective. Plant Science, v. 161, n. 5, pp. 839-851.

Brancalion P.H.S., Viani R.A.G., Strassburg B.B.N., Rodrigues R.R. 2012. Finding the money for tropical forest restoration. Unasylva, pp. 239

Canuto, J.Z., Alves-Pereira, A., Côrtes, M.C. 2014. Genética nos Estudos com Polinização. In: A.R. Rech, K. Agostini, P.E. Oliveira, I.C. Machado. Biologia da Polinização. Projeto Cultural, Rio de Janeiro, 20: 439-460.

Clark M.S. 1997. Plant Molecular Biology - A laboratory manual. Springer-Verlog, Berlin Heidelberg, pp. 305-328.

Carvalho, C.S., Ribeiro, M. C., Côrtes, M.C., Galetti, M., \& Collevatti, R. G. 2015. Contemporary and historic factors influence differently genetic differentiation and diversity in a tropical palm. Heredity, v. 115, n. 3, pp. 216. 
Carvalho, C.S., Valverde, J., Souza, M., Ribeiro, T., Nazareth, S., Galetti, M., Côrtes, M. 2019. La dispersión de semillas en bosques remanentes tropicales: el papel de los zorzales en el mantenimiento de la estructura y diversidad genética de Euterpe edulis. Ecosistemas (Madrid. Internet), v. 28, pp. 26-34, 2019.

Clemente, M.S. 2010. Análise da variação genética de populações de Vochysia pyramidalis e V. tucanorum por AFLP e da composição de ácidos graxos de sementes. 2010. Dissertação de Mestrado, Universidade de São Paulo, São Paulo.

Conte, R. Nodari R.O., Vencovsky R., Reis M.S. 2003. Genetic diversity and recruitment of the tropical palm, Euterpe edulis Mart., in a natural population from the Brazilian Atlantic Forest. Heredity, v. 91, pp. 401-406.

Dawson C.R., Magee R.R. 1995. Plant tyrosinase (polyphenol oxidase). In: S.P. Colowick, N.O. Kaplan (eds.). Methods in Enzymology. v. 2. Academic Press New York, pp. 817-827.

Di Bonito, R. I. T. A., Elliott, M. L., Des Jardin, E. A. 1995. Detection of an arbuscular mycorrhizal fungus in roots of different plant species with the PCR. Applied and Environmental Microbiology, v. 61, n. 7, pp. 2809-2810.

Reis, M.S., Fantini A.C., R.O. Nodari R. O., Reis A., Guerra M.P., Mantovani A. 2000. Management and conservation of natural populations in Atlantic Rain Forest: The case study of palm heart (Euterpe edulis Martius). Biotropica 32: 894-902.

Doyle J., Doyle J.L. 1987. Genomic plant DNA preparation from fresh tissue-CTAB method. Phytochemical Bulletin 19: 11-15.

Ellstrand N.C. 1992. Gene flow by pollen: Implications for plant conservation genetics. Oikos: 63: 77-86.

Gaiotto, F.A., Brodani, R.P.V, \& Grattapaguia, D. 2001. Microsatellite markers for heart of palm - Euterpe edulis and E. oleracea Mart. (Arecaceae). Molecular Ecology, Notes, 1: 86-88.

Gaiotto, F. A., Grattapaglia, D., Vencovsky, R. 2003. Genetic structure, mating system, and long distance gene flow in heart of palm (Euterpe edulis Mart.). Journal of Heredity 94: 399-406.

Galetti, M., Ziparro, V., Morellato, L.P. 1999. Fruiting phenology and frugivory on the palm Euterpe edulis in a lowland Atlantic forest of Brazil. Ecotropica 5: 115-122.

Galetti, M., Guevara, R., Côrtes, M.c., Fadini, R., Vonmatter, S., Leite, A.B., Labecca, F., Ribeiro, T., Carvalho, C.S., Collevatti, R.G., Pires, M.M., Guimarães Jr, P.R., Bracalion, P.H.S, Ribeiro, M.C., Jordano, P. 2013. Functional extinction of birds drives rapid evolutionary changes in seed size. Science 340: 1086-1090.

García, C., Jordano, P., Arroyo, J. M., \& Godoy, J. A. 2009. Maternal genetic correlations in the seed rain: effects of frugivore activity in heterogeneous landscapes. Journal of Ecology 97: 1424-1435.
García, C., Jordano, P., Godoy J.A. 2007. Contemporary pollen and seed dispersal in a Prunus mahaleb population: patterns in distance and direction. Molecular Ecology 16: 1947-1955.

García C., Grivet D. 2011. Molecular insights into seed dispersal mutualisms driving plant population recruitment. Acta Oecologica 37: 632-640.

Grivet D., Smouse P.E., Sork V.L. 2005. A novel approach to an old problem: tracking dispersed seeds. Molecular Ecology 14: 3585-3595.

Godoy, J.A., \& Jordano, P. 2001. Seed dispersal by animals: exact identification of source trees with endocarp DNA microsatellites. Molecular Ecology 10: 2275-2283.

Gonzalez-Varo, J.P., Arroyo, J., Aparicio, A. 2009. Effects of fragmentation on pollinator assemblage, pollen limitation and seed production of mediterranean Myrtle (Myrtus communis). Biological Conservation 142: 1058-1065.

Hamrick, J.L. 1982. Plant Population Genetics and Evolution. American Journal of Botany 69: 1685-1693.

Hamrick, J.L. \& Loveless, M.D. 1989. The genetic structure of tropical tree populations: Associations with reproductive biology. In: J. Bock \& Y.B. Linhart (eds.). The Evolutionary Ecology of Plants. Westview Press, Boulder, Colorado, pp. 129-146.

Haig, S. 1998. Molecular contributions to conservation. Ecology 79: 413-425.

Hypolito, G.B. 2018. Dispersão de pólen e sistema reprodutivo da palmeira Euterpe edulis em fragmentos da Mata Atlântica. Trabalho de conclusão de curso. Universidade Estadual Paulista "Júlio de Mesquita Filho".

ITESP - Instituto de Terras do Estado de São Paulo "José Gomes da Sila". 1998. Relatório técnico-científico sobre a comunidade do Quilombo de Ivapurunduva, localizada no município de Eldorado no vale do Ribeira. Eldorado. Secretaria da Justiça e da defesa da cidadania do estado de São Paulo.

Khanuja S.P.S., Shasany A.K., Darokar M.P., Kumar S. 1999. Rapid isolation of DNA from dry and fresh samples of plants producing large amounts of secondary metabolites and essential oils. Plant Molecular Biology Reporter 17: 1-7.

Korbie, D.J., \& Mattick, J.S. 2008. Touchdown PCR for Increased Specificity and Sensitivity in PCR Amplification, Nature Protocols 3: 1452-1456.

Lanes E.C.M., Nick C., Kuki K.N., Freitas R.D., Motoike S.Y. 2013. Genomic DNA isolation of Acrocomia aculeata (Arecaceae) from leaf and stipe tissue samples for PCR analysis. Genetics and Molecular Research 12: 3905-3911.

Ledig, F.T. \& Conkle, M.T. 1983. Gene diversity and genetic structure in a narrow endemic, Torrey pine (Pinus torreyana Parry ex Carr). Evolution 37: 79-85. 
Lewinsohn, E., Steele, C.I. \& Croteau, R. 1994. Simple isolation of functional RNA from woody stems of gymnosperms. Plant Molecular Biology Reporter 12: $20-25$.

Mantovani, A. \& Morellato, L.P.C. 2000. Fenologia da floração, frutificacão, mudança foliar e aspectos da biologia floral. In: M.S. Reis, A. Reis (eds.). Euterpe edulis Martius - Palmiteiro: biologia, conservação e manejo. Herbario Barbosa Rodrigues, Itajaí, pp. 23-38.

Marrero, P., Fregel, R., Cabrera, V.M, \& Nogales, M. 2009. Extraction of high-quality host DNA from feces and regurgitated seeds: a useful tool for vertebrate ecological studies. Biological Research 42: 147-151.

Milligan, B.G. 1989. Purification of chloroplast DNA using hexadecyltrimethylammonium bromide. Plant Molecular Biology Reporter 7: 144-149.

Murray, M.G., Thompson, W.F. 1980. Rapid isolation of high molecular weight plant DNA. Nucleic Acids Research 8: 4321-4325.

Ouborg N.J., Piquot Y. \& Van Groenendael J.M. 1999. Population genetics, molecular markers and the study of dispersal in plants. Journal of Ecology 87: 551-568.

Puchooa, D. 2004. A simple, rapid and efficient method for the extraction of genomic DNA from lychee (Litchi chinensis Sonn.). African Journal of Biotechnology 3: 253-255.

Puglisi E., Pascazio S., Suciu N., Cattani I., Fait G., Spaccini R., Crecchio C., Piccolo A. \& Trevisan M. 2013. Rhizosphere microbial diversity as influenced by humic substance amendments and chemical composition of rhizodeposits. Journal of Geochemical Exploration 129: 82-94.

Reis, A. \& Kageyama, P.Y. 2000. Dispersão de sementes do palmiteiro (Euterpe edulis Martius - Palmae). In: M.S. Reis, \& A. Reis (eds.). Euterpe edulis Martius (Palmiteiro): biologia, conservação e manejo. Herbário Barbosa Rodrigues. Sellowia 45: 60-92.

Rogers S.O., Bendich A.J. 1994. Extraction of total cellular DNA from plants, algae and fungi. In: S.B. Gelvin, R.A. Schilperoort (eds.). Plant molecular biology manual. Kluwer Academic Publishers, Dordrecht.

Schori, M., Appel, M., Kitko, A.,Showalter, A.M. 2013. Engineered DNA polymerase improves PCR results for plastid DNA. Applications in Plant Sciences 1: 1-7.
Seoane, C.E.S., Sebbenn, A.M., Kageyama, P.Y. 2005. Sistema de reprodução em duas populações naturais de Euterpe edulis M. sob diferentes condições de fragmentação florestal. Scientia Forestalis 69: 13-24.

Sobierajski, G.R., Kageyama, P.Y., Sebbenn, A.M. 2006. Estimates of genetic parameters in Mimosa scabrella popilations by rondom and mixed reproduction models. Crop Breeding and Applied Biotechnology 6: 47-54.

Solléro B.P., Faria,D.A., Paiva, S.R., Guimarãoes, S.E.F., Lopes, P.S. \& Paixão D.M. 2004. Método rápido de estração de DNA utilizando CTAB em tecidos musculares de suínos. In: Congresso Internacional de Zootecnia, Brasília.

Souza, S.E.X.F. 2014. Manejo de Euterpe edulis Mart. para produção de polpa de fruta: subsídios à conservação da biodiversidade e fortalecimento comunitário. Tese de Doutorado, Universidade de São Paulo, Piracicaba.

Lucas, M.S. 2016. Limitação da dispersão pela distância e diversidade genética das sementes dispersas de Palmito Juçara em fragamentos da Mata Atlântica. Trabalho de Conclusão de Curso. Universidade Estadual Paulista "Júlio de Mesquita Filho", Rio Claro.

Stevenson, F.J. 1996. Humus chemistry, Wiley, New York. Tarazi, R., Sebbenn, A.M., Kageyama, P. Y., \& Vencovsky, R. 2013. Edge effects enhance selfing and seed harvesting efforts in the insect-pollinated Neotropical tree Copaifera langsdorffii (Fabaceae). Heredity 110: 578-585.

Tel-Zur N., Abbo S., Myslabodski D., Mizrahi Y. 1999. Modified CTAB procedure for DNA isolation from epiphytic cacti of the genera Hylocereus and Selenicereus (Cactaceae). Plant Molecular Biology Reporter 17: 249-254.

Varma A., Padh, H., Shrivastavan, N. 2007. Plant genomic DNA isolation: an art or a science. Biotechnology Journal 2: 386-92

Varner, J.E. \& Lin, L.-S. 1989. Plant cell wall architecture. Cell 56: 231-239.

Waldschmidt, A.M. 1999. Análises Genética e Morfométrica de Populações de Melipona quadrifasciata Lep. (Hymenoptera: Apidae; Meliponinae). Tese Doutorado, Universidade Federal de Viçosa, Viçosa.

Williams, C.E., Ronakd, P.C. 1994. PCR template- DNA isolated quickly from monocot and dicot leaves without tissue homogenization. Nucleic Acids Research 22: 1917-1918. 